\title{
Comparison of Simple vs. Complex Concentrate Mixtures for Dairy Cattle in Puerto Rico: Feeding Heifers in Dry Lot
}

\author{
Paul F. Randel ${ }^{1}$ \\ INTRODUCTION
}

Since dairy heifers give no immediate monetary return to the dairy farmer, it is economically desirable to feed them a ration which, while enabling them to achieve an adequate rate of body growth and undergo normal physiological development, is as inexpensive as possible. In regions such as the Lajas Valley of Puerto Rico, where pastures are typically unproductive for a considerable part of the year, and harvested forages are available only in limited quantities, it is usually necessary to supplement dairy-heifer rations with concentrates. The results of research to determine the least expensive yet nutritionally adequate mixtures of concentrate feeds for dairy heifers should contribute to the economical efficiency of dairy-cattle feeding in Puerto Rico. The present experiment, which was conducted in conjunction with another involving lactating cows, a simple low-cost concentrate mixture was tested on growing heifers in comparison with a more expensive complex mixture fortified with many specific nutrients.

\section{REVIEW OF LITERATURE}

A number of reports have appeared in the literature of experiments comparing simple versus complex mixtures of concentrate feeds in the rations of lactating dairy cows, as reviewed in the first paper of the series $(4)^{2}$. However, to the author's knowledge, only one experiment has been reported in which a comparison of this type was made on growing heifers (2). In that experiment, which was conducted in Ohio, heifer calves were fed from 10 days until 6 months of age one of the two concentrate mixtures, and alfalfa or clover hay, plus whole milk until 4 weeks of age, followed by skim milk until 4 months of age.

The complex concentrate mixture contained ground shelled corn, ground oats, wheat bran, linseed-oil meal, soybean-oil meal, dried skim milk, bonemeal, limestone, and salt, while the simple mixture contained only whole corn, whole oats, and salt. During the fifth and sixth months, the heifers on the simple-concentrate treatment were given sufficient skim

1 Associate Nutritionist, Agricultural Experiment Station, University of Puerto Rico, Substation, Lajas, P.R.

2 Italic numbers in parentheses refer to Literature Cited, pp. 348-9. 
milk in liquid form to equalize their intake of skim milk with that of the other heifers which received skim milk in their concentrate mixture. The 34 heifers fed the complex concentrate mixture gained an average of 1.23 pounds per day while the 31 heifers fed the simple mixture gained an average of 1.20 pounds per day. The difference between treatments was not statistically significant.

\section{MATERIALS AND METHODS}

This experiment consisted of a 44-week continuous feeding trial to compare a simple versus a complex concentrate mixture for growth in dairy heifers of prebreeding age maintained in drylot.

\section{ANIMALS AND HOUSING}

Twelve dairy heifers, including ten Holstein and two Brown Swiss, were selected from the Substation herd for use in this experiment. The heifers were divided into four groups of three each. Groups 1 and 2, each of which included one Brown Swiss heifer, were balanced as equally as possible with regard to age and initial body weight, and groups 3 and 4 were similarly balanced. The averaged ages in days of the heifers in groups 1 through 4 at the start of the experiment were $254,238,160$, and 165 , respectively.

Groups 1 and 3 were assigned to the simple-concentrates treatment and groups 3 and 4 to the complex-concentrates treatment. Throughout the experiment groups 1 and 2 were maintained in outdoor pens. Groups 3 and 4 were housed in indoor pens for the first half of the experiment and then moved to outdoor pens for the second half. Bagasse bedding was used in the indoor pens; the outdoor pens were not bedded. All the pens had concrete floors and provided shade for the animals.

\section{RATIONS}

The two experimental rations differed only in concentrate mixture. The concentrate mixtures were the same as those employed in an experiment which was conducted simultaneously with lactating cows, and are described in detail in the first paper of this series (4). During the present experiment 11 lots of simple and 6 of complex concentrate mixture were employed. Six pounds of concentrate mixture per head were fed daily in two equal portions to all four groups throughout the experiment.

Individual feeding was simulated by placing three mangers at different locations in each pen, so that it was not possible for any heifer to steal very much of another heifer's allowance of concentrates. The remainder of the ration consisted of green forage and sorghum silage. At various periods during the course of the experiment, sorghum (Sorghum vulgare), Guinea 
grass (Panicum maximum), and merkergrass (Pennisetum purpureum) served as the green forage, of which 2 pounds were fed per head daily. The green forages, ranged from 13.94 to 24.20 percent in dry-matter content, and from 6.65 to 12.51 percent in crude-protein content, while the sorghum silage ranged from 16.70 to 31.76 percent in dry-matter content and from 5.01 to 8.26 percent in crude-protein content, as determined by A.O.A.C., procedures (1).

At the start of the experiment the silage allowances of groups 1 and 2 and of groups 3 and 4 were 18 and 8 pounds per head daily, respectively. These were increased gradually and reached 28 pounds per head daily for all four groups in the latter stages of the experiment. The daily silage allowance was always fed in two equal portions. Uneaten silage was weighed once daily. The allowances of green forage and concentrate mixture were assumed to be completely consumed. The rations were estimated to supply the heifers with digestible energy and digestible protein slightly in excess of their requirements for normal growth, as published by the Committee on Animal Nutrition of the National Research Council (8). The heifers had free access to water in their pens, but were provided with no extra salt.

\section{BODY-WEIGHT DETERMINATIONS}

All body-weight determinations after those at the beginning of the adjustment period were made on the heifers after they had passed the night of 16 to 17 hours in a holding area with access to neither feed nor water. The heifers were weighed on the first day of each experimental period and on the day following the final experimental period. Body weights were recorded to the nearest pound.

\section{STATISTICAL ANALYSIS}

The experiment was divided into 11 periods, each of 4 weeks duration. The first period was considered as adjustment and data collected were not included in the statistical analysis of the experimental results. The following 10 periods constituted the comparison period. Each group of heifers remained under the same treatment during the entire experiment. The data were analyzed for each individual experimental period and for the experiment as a whole. The data pertaining to live-weight gain were analyzed by analysis of variance and the data pertaining to efficiency of utilization of dry matter consumed for live-weight gain were analyzed on a group basis by the paired $t$ test, as outlined by Snedecor (5).

\section{RESULTS}

Both of the concentrate mixtures were readily eaten by the heifers. The amounts of concentrate mixture and of green forage consumed were as- 
sumed to be the same for all four groups and totaled 5,040 and 1,680 pounds, respectively, per group during the 40-week comparison period. Approximately 96 percent of all silage offered was consumed. The quantities of silage consumed during the comparison period by groups 1 through 4 were $20,638,20,666,18,845$, and 20,314 pounds, respectively. The corresponding figures for total ration dry matter consumed were 10,127, 10,265, 9,649, and 10,175 pounds, respectively; while those for total crude protein consumed were $1,049,1,067,1,022$, and 1,062 pounds, respectively.

The rate of live-weight gain of the heifers in this experiment (table 1) was generally satisfactory. The live-weight gains recorded during individual experimental periods were highly variable, for which no explanation is

TABLE 1.-Mean live-weight gains of the experimental heifers (pounds per day)

\begin{tabular}{|c|c|c|c|c|c|c|}
\hline \multirow{2}{*}{ Period } & \multicolumn{3}{|c|}{$\begin{array}{l}\text { Heifers on simple-concentrate } \\
\text { ration }\end{array}$} & \multicolumn{3}{|c|}{$\begin{array}{l}\text { Heifers on complex-concentrate } \\
\text { ration }\end{array}$} \\
\hline & Group 1 & Group 3 & Mean & Group 2 & Group 4 & Mean \\
\hline 1 & 1.36 & 1.71 & 1.54 & 1.02 & 1.46 & 1.24 \\
\hline 2 & .67 & 1.00 & .83 & .71 & 1.37 & 1.04 \\
\hline 3 & 1.23 & 1.67 & 1.45 & 1.46 & 1.43 & 1.45 \\
\hline 4 & .98 & 1.13 & 1.05 & 1.00 & 1.02 & 1.01 \\
\hline 5 & 1.08 & .38 & .73 & .70 & .80 & .75 \\
\hline 6 & .83 & 1.76 & 1.30 & .63 & 1.35 & .99 \\
\hline 7 & 1.35 & 1.05 & 1.20 & 1.42 & 1.11 & 1.26 \\
\hline 8 & .80 & .69 & .74 & .92 & .96 & .94 \\
\hline 9 & 1.46 & 1.07 & 1.27 & 1.13 & .98 & 1.05 \\
\hline 10 & .79 & 1.12 & .95 & .55 & .44 & .49 \\
\hline Entire experiment & 1.05 & 1.16 & 1.11 & .95 & 1.09 & 1.02 \\
\hline
\end{tabular}

readily apparent. Over the entire comparison period the heifers consuming the simple concentrate mixture gained slightly more than the heifers consuming the complex mixture, however, the difference between treatments was not statistically significant. The mean body weight of groups 1 through 4 , respectively, at the start and at the end of the comparison period were $371,379,321$, and 317 ; and $666,646,645$, and 623 pounds.

Since the proportions of concentrate mixture and of forage consumed were practically the same for all groups, it was felt that a meaningful comparison of feed-utilization efficiency could be made by calculating the ratio of pounds of dry matter consumed per pound of live-weight gain (table 2). This ratio was extremely variable during individual experimental periods. Over the entire comparison period, however, the feed-utilization efficiency was better in the heifers consuming the simple concentrate mixture, the difference being statistically significant $(P<0.05)$. 
The feed cost for each group of heifers was calculated from the quantity of each feed given and its respective cost. The cost of the simple concentrate mixture, after making an allowance of $\$ 0.15$ per 100 pounds for the costs of grinding corn and mixing at the Substation, ranged from $\$ 3.99$ to $\$ 4.82$ per 100 pounds as the cost of ingredients fluctuated. The costs of the complex concentrate mixture, delivered at the Substation, varied among lots from $\$ 4.64$ to $\$ 4.80$ per 100 pounds. The costs of silage and of green forage were estimated as $\$ 0.50$ and $\$ 2.00$ per 100 pounds, respectively. The cost of green forage was high because it was harvested by hand. Based upon

TABLE 2.-Pounds of dry matler consumed by heifers (group basis) per pound of live-weight gain

\begin{tabular}{|c|c|c|c|c|c|c|}
\hline \multirow{2}{*}{ Period } & \multicolumn{3}{|c|}{$\begin{array}{l}\text { Heifers on simple-concentrate } \\
\text { ration }\end{array}$} & \multicolumn{3}{|c|}{$\begin{array}{l}\text { Heifers on comples-concentrate } \\
\text { ration }\end{array}$} \\
\hline & Group 1 & Group 3 & Mean & Group 2 & Group 4 & Mean \\
\hline 1 & 8.08 & 6.19 & 7.14 & 10.94 & 7.52 & 9.23 \\
\hline 2 & 17.61 & 11.33 & 14.47 & 16.91 & 8.89 & 12.90 \\
\hline 3 & 9.45 & 6.07 & 7.76 & 8.06 & 7.47 & 7.76 \\
\hline 4 & 11.88 & 9.79 & 10.84 & 11.70 & 11.46 & 11.58 \\
\hline 5 & 11.16 & 29.63 & 20.40 & 17.31 & 15.25 & 16.28 \\
\hline 6 & 14.94 & 6.37 & 10.66 & 19.73 & 8.86 & 14.30 \\
\hline 7 & 9.72 & 12.11 & 10.92 & 9.26 & 11.98 & 10.62 \\
\hline 8 & 17.46 & 19.84 & 18.65 & 15.59 & 15.04 & 15.32 \\
\hline 9 & 8.87 & 11.94 & 10.40 & 11.77 & 13.85 & 12.81 \\
\hline 10 & 12.90 & 8.97 & 10.94 & 18.44 & 23.08 & 20.76 \\
\hline Entire experiment & 11.44 & 9.92 & $10.68 * 1$ & 12.80 & 11.10 & 11.95 \\
\hline
\end{tabular}

$1 *$ Difference between means significant at the 5-percent level of probability $(P<0.05)$.

these figures the total feed costs per heifer over the 40-week comparison period for groups 1 through 4 were $\$ 117.09, \$ 125.53, \$ 115.94$, and $\$ 124.38$, respectively. The corresponding feed costs per pound of live-weight gain were $\$ 0.40, \$ 0.47, \$ 0.36$, and $\$ 0.41$, respectively. The feed cost per pound of live-weight gain of all heifers consuming the simple concentrate mixture was $\$ 0.38$ and that of all heifers consuming the complex concentrate mixture was $\$ 0.44$.

\section{DISCUSSION}

In this experiment the complex concentrate mixture, which included a multitude of ingredients and supplementation with minerals, vitamins, and antioxidants, was not found to be any more effective in promoting 
live-weight gains in dairy heifers than a far simpler concentrate mixture supplemented with bonemeal and salt only. In fact, by the criterion of utilization efficiency of ingested dry matter for live-weight gain, it was found that the simple concentrate mixture was superior to the complex. An explanation of this apparently greater nutritive value of the simple concentrate mixture under the conditions of this experiment is difficult because the exact composition of the complex mixture is not available.

From consideration of the chemical analyses, which are presented in another paper in this issue of the Journal (4), it may be speculated that the simple concentrate mixture, which analyzed lower in crude fiber and ash and higher in nitrogen-free extract, was higher in digestible energy content than the complex mixture. Only 2.5 percent of the simple concentrate mixture consisted of ingredients which supplied the animal with no digestible energy. It is likely that this percentage was higher in the complex mixture. Furthermore, the simple concentrate mixture contained 67.5 to 75.0 percent of ground shelled corn, which is one of the highest in energy of concentrate feeds. Differences in protein intakes could not have caused any of the observed difference in response to the two treatments, since these were greater in the heifers consuming the complex concentrate mixture.

The economic advantage of the simple concentrate mixture was demonstrated by the saving of $\$ 0.06$ on the feed cost per pound of live-weight gain, after allowing for the cost involved in preparing this concentrate mixture at the Substation. It definitely appears that the use of simple concentrate mixtures, prepared from the least expensive yet nutritionally adequate ingredients available, could help to reduce the cost of rearing heifers under the conditions of the Lajas Valley.

\section{SUMMARY AND CONCLUSIONS}

Twelve heifers, including ten Holstein and two Brown Swiss were divided into four groups of three heifers each. Two of the groups, in which the heifers averaged 207 days of age at the start, were assigned to a ration containing a simple concentrate mixture while the other two groups, in which the heifers averaged 202 days of age at the start, were assigned to a ration containing a complex concentrate mixture for a continuous feeding trial, which involved 4 weeks of adjustment and 40 weeks of comparison period. Each group was fed daily 6 pounds per head of its respective concentrate mixture plus 2 pounds per head of green forage and an allowance of sorghum silage which increased gradually up to 28 pounds per head. Sixteen-hour shrunk-weights of heifers were obtained every fourth week.

The average daily live-weight gains over the entire comparison period for heifers consuming the simple and complex concentrate mixtures were 
1.11 and 1.02 pounds, respectively. This difference was not statistically significant. The average pounds of dry-matter intake required per pound of live-weight gain was significantly $(P<0.05)$ less for heifers consuming the simple than for those consuming the complex-concentrate mixture (10.68 vs. 11.95 pounds). The feed costs per pound of live-weight gain in heifers consuming the simple and complex concentrate mixtures were estimated as $\$ 0.38$ and $\$ 0.44$ respectively.

It is concluded that simple concentrate mixtures which are entirely equal nutritionally to more complex mixtures for growing heifers can be prepared at the farm from purchased ingredients at a saving in cost.

\section{RESUMEN Y CONCLUSIONES}

Doce novillas, inclusive 10 de la raza Holstein y 2 de la Pardo Suiza, fueron divididas en cuatro grupos de tres novillas cada uno. Dos de los grupos, cuyas novillas tenían un promedio de 207 días de edad al empezar el estudio, recibieron una ración consistente de una mezcla sencilla de alimentos concentrados, mientras que los otros dos grupos, cuyas novillas promediaban 202 dias de edad al empezar, se alimentaron con una mezcla compleja de alimento concentrado, en una prueba de alimentación contínua, durante un período de adaptación de 4 semanas y $\mathbf{4 0}$ semanas para un estudio comparativo de los tratamientos. A cada novilla de cada grupo se le dieron diariamente 6 libras del alimento concentrado que le correspondía, más 2 libras por cabeza, de forraje verde y una cantidad de ensilaje de millo que aumentó gradualmente hasta alcanzar 28 libras. Se pesaron las novillas cada cuatro semanas después de 16 horas sin agua ni comida.

$\mathrm{El}$ promedio de ganancia diaria en peso vivo durante el período de comparación fue de 1.11 libras en las novillas que consumieron la mezcla sencilla y de 1.02 libras en las que consumieron la mezcla compleja. Esta diferencia no fue estadísticamente significativa. Por cada libra de ganancia en peso vivo, las novillas alimentadas con la mezcla sencilla requirieron un promedio de 10.68 libras de materia seca, mientras que las que consumieron la mezcla compleja requirieron 11.95 libras. Esta diferencia fue significativa $(P<0.05)$. Los costos de alimentación por libra de ganancia en peso vivo se calcularon en $\$ 0.38$ para las novillas que consumieron la mezcla sencilla y en $\$ 0.44$ para las que consumieron la mezcla compleja.

De estas pruebas se concluye que, utilizando ingredientes comprados, es posible preparar en la finca, a un bajo costo, mezclas sencillas de alimentos concentrados, cuyo valor nutritivo sea igual al de las mezclas complejas para la nutrición de novillas en estado de crecimiento.

\section{LITERATURE CITED}

1. Assoc. Official Agr. Chem., Official Methods of Analysis, 9th ed., Washington, D.C., 1960. 
2. Krauss, W. E., and Monroe, C. F., Simple vs. complex grain mixtures in dairy rations IV: Heifer calves raised for replacements and veals for slaughter, Ohio Agr. Expt. Sta. Bimonthly B. 241: 97-9, 1946.

3. National Research Council, Committee on Animal Nutrition, Nutrient requirements of dairy cattle, Nat. Acad. Sci., Nat. Res. Council Pub. 464. 1958.

4. Randel, P. F., Comparison of simple vs. complex concentrate mixtures for dairy cattle in Puerto Rico: Feeding lactating cows receiving fair-quality forage, $J$. Agr. Univ. P.R. 49 (3): 331-41.

5. Snedecor, G. W., Statistical Methods, 5th ed. Iowa State College Press, Ames, Iowa, 1956. 